\title{
The convergent epidemiology of tuberculosis and human
}

\section{cytomegalovirus infection [version 1; peer review: 1 approved,}

\section{1 approved with reservations]}

\author{
Frank Cobelens (D1), Nico Nagelkerke², Helen Fletcher (D)3 \\ ${ }^{1}$ Department of Global Health and Amsterdam Institute for Global Health and Development, Academic Medical Center, \\ Meibergdreef 9, AZ, Amsterdam, 1105, The Netherlands \\ ${ }^{2}$ Department of Medical Microbiology, University of Manitoba, Basic Medical Sciences Building, 745 Bannatyne Avenue, Winnipeg, \\ $\mathrm{MB}, \mathrm{R} 3 \mathrm{E}$ 0J9, Canada \\ ${ }^{3}$ TB Centre, London School of Hygiene \& Tropical Medicine, Keppel Street, London , WC1E 7HT, UK
}

V1 First published: 06 Mar 2018, 7:280

https://doi.org/10.12688/f1000research.14184.1

Latest published: $30 \mathrm{Apr}$ 2018, 7:280

https://doi.org/10.12688/f1000research.14184.2

\section{Abstract}

Although several factors are known to increase the risk of tuberculosis, the occurrence of tuberculosis disease in an infected individual is difficult to predict. We hypothesize that active human cytomegalovirus infection due to recent infection, reinfection or reactivation plays an epidemiologically relevant role in the aetiology of tuberculosis by precipitating the progression from latent tuberculosis infection to disease. The most compelling support for this hypothesis comes from the striking similarity in age-sex distribution between the two infections, important because the age-sex pattern of tuberculosis disease progression has not been convincingly explained. Cytomegalovirus infection and tuberculosis have other overlapping risk factors, including poor socio-economic status, sexual contact, whole blood transfusion and solid organ transplantation. Although each of these overlaps could be explained by shared underlying risk factors, none of the epidemiological observations refute the hypothesis. If this interaction would play an epidemiologically important role, important opportunities would arise for novel approaches to controlling tuberculosis.

\section{Keywords}

Tuberculosis, latent tuberculosis infection, human cytomegalovirus, epidemiology, age pattern, risk factor

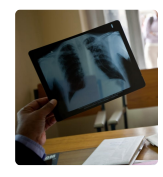

This article is included in the World TB Day

collection.

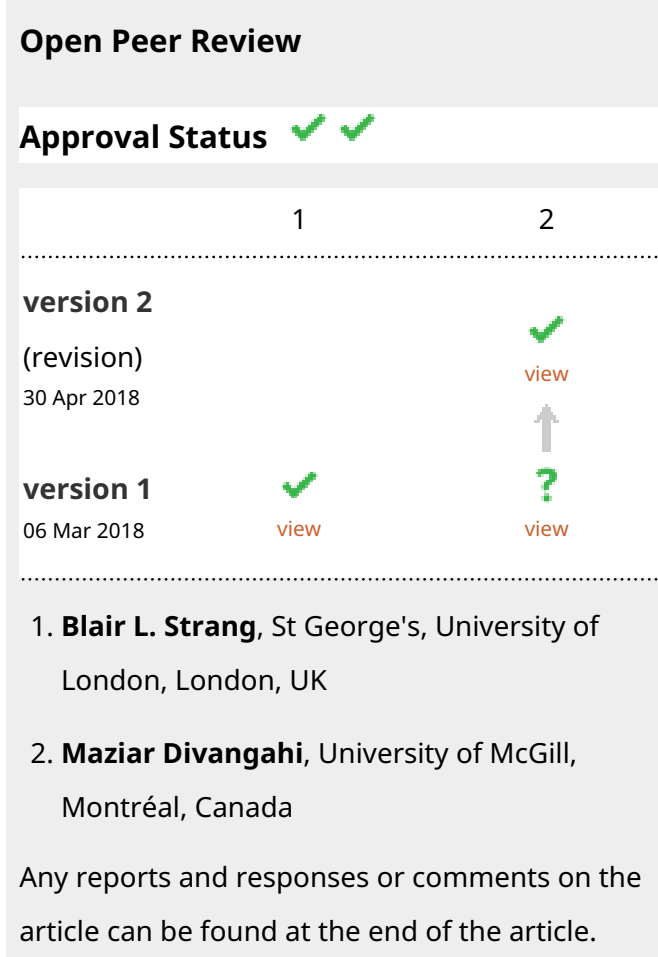


Corresponding author: Frank Cobelens (f.cobelens@aighd.org)

Author roles: Cobelens F: Conceptualization, Writing - Original Draft Preparation, Writing - Review \& Editing; Nagelkerke N: Conceptualization, Writing - Review \& Editing; Fletcher H: Conceptualization, Writing - Review \& Editing

Competing interests: No competing interests were disclosed.

Grant information: The author(s) declared that no grants were involved in supporting this work.

Copyright: (c) 2018 Cobelens F et al. This is an open access article distributed under the terms of the Creative Commons Attribution License, which permits unrestricted use, distribution, and reproduction in any medium, provided the original work is properly cited.

How to cite this article: Cobelens F, Nagelkerke $\mathrm{N}$ and Fletcher $\mathrm{H}$. The convergent epidemiology of tuberculosis and human cytomegalovirus infection [version 1; peer review: 1 approved, 1 approved with reservations] F1000Research 2018, 7:280 https://doi.org/10.12688/f1000research.14184.1

First published: 06 Mar 2018, 7:280 https://doi.org/10.12688/f1000research.14184.1 


\section{Introduction}

With 10.4 million new cases and 1.7 million deaths per year, tuberculosis (TB) remains a major global health problem ${ }^{1}$. Only 5\%-15\% of individuals infected with Mycobacterium tuberculosis (Mtb) ever develop TB disease, and over 50\% of these do so within two years after infection ${ }^{2}$. Although risk factors for progression to TB disease have been identified ${ }^{3}$, disease occurrence cannot be accurately predicted ${ }^{4}$.

Recent data suggest that infection with human cytomegalovirus (HCMV) is a predictor of TB disease in infants. In a cohort study of South African infants, an HCMV-specific IFN- $\gamma$ T-cell response was associated with a 2.2-fold increased risk of TB disease over a period of up to 3 years. A similar response to Epstein-Barr virus (EBV) showed no such associations ${ }^{5}$. HCMV-positive and HCMV-negative infants had distinct immune pathways associated with TB disease. Although CD8+ T-cell activation was a distinguishing feature of HCMVpositive infants, the proposed immunological mechanism was impairment of the natural killer (NK) cell response. In African infants, HCMV infection induced profound CD8+ T-cell and NK cell differentiation and poor physical growth ${ }^{5-7}$.

The possibility that this association between HCMV and TB disease progression is causal, also holds in adults, and thus merits further study is dependent on its epidemiological plausibility. Only few published studies have investigated epidemiological associations between the two diseases ${ }^{8-10}$. Despite this paucity of direct evidence we argue that the epidemiology of TB and HCMV share important similarities that make HCMV infection a plausible candidate as a cause of TB disease progression.

\section{Viral triggers of tuberculosis disease}

Various etiological frameworks for TB disease progression have been developed. One proposed by Comstock considers TB disease the result of two hits or causes, one of which is Mtb infection, and the other (still) unknown ${ }^{11}$. In this framework, factors that strongly increase the risk of $\mathrm{TB}$ disease such as HIV infection or anti-tumour necrosis alpha therapy may act as a second hit but would not account for all or most TB cases.

Several factors have been identified that increase the risk of disease progression, such as low body-mass index ${ }^{12}$, diabetes ${ }^{13}$, tobacco smoking ${ }^{14}$, and alcohol abuse ${ }^{15}$. As their effects are modest another framework has emerged that these are predisposing conditions for disease progression while other, yet unidentified precipitating events are needed to trigger progression to active disease ${ }^{16}$. Among the precipitating events suggested are respiratory viral infections, notably influenza A. Influenza A induces type I interferons that impair immunity against mycobacteria ${ }^{17}$. Also, notification of TB tends to peak in the months after winter when most respiratory viruses circulate $^{18}$, and TB mortality has shown increases during influenza epidemics ${ }^{19,20}$. However, careful analysis of seasonality data suggests that it is TB transmission rather than disease progression that is increased in winter $^{21}$. HCMV has been suggested in three studies from
Nigeria, Russia and Uganda that all found higher prevalence or levels of IgG HCMV antibodies in diagnosed TB patients compared to healthy controls and patients diagnosed with other disease $^{8-10}$.

\section{Human cytomegalovirus infection}

HCMV, human herpesvirus 5, is a double-stranded DNA virus. After primary infection, usually through mucosal contact, HCMV remains dormant in the host's myeloid tissues but can reactivate if immunity is compromised. Primary infection is often asymptomatic but can present as mononucleosis with fever, pharyngo-tonsillitis and lymphadenopathy. In congenitally infected infants HCMV may cause severe generalized infection with high case fatality and neurologic sequelae ${ }^{22}$. Generalized infection also occurs in severely immunocompromised adults, usually through reactivation. During primary infection and reactivation virus is shed in the urine, saliva, breast milk, cervical fluid and $\operatorname{semen}^{23}$. Common routes of transmission are from mother to child during delivery, between children and by sexual contact. Transmission through blood transfusion and solid organ transplantations also occurs.

HCMV viruses show genomic diversity, in particular in genes coding for envelope glycoproteins, and polymorphisms in these genes have been used to genotype strains ${ }^{24,25}$. Both immunocompromised and immunocompetent individuals can be re-infected and harbour multiple HCMV strains ${ }^{26-28}$.

Primary HCMV infection is characterized by profound expansion of antigen specific CD8+ and CD4+ $\mathrm{T}$ cells and $\mathrm{NK}$ cell populations with specificity for $\mathrm{HCMV}^{29}$. HCMV expanded NK cells can display inappropriate homing to tissue infected with other pathogens and lower IFN- $\gamma$ secretion in response to pathogens ${ }^{30}$. HCMV has multiple immune evasion strategies ${ }^{29}$, which may make the microenvironment around latently infected myeloid cells suppressive to T-cell function, potentially creating an environment permissive for mycobacterial growth ${ }^{31}$.

The lung is a reservoir of HCMV infection and frequently the site of viral reactivation, which drives inflammation and in mice may cause pulmonary fibrosis ${ }^{32}$. It is therefore possible that replication of $\mathrm{Mtb}$ in the lungs could lead to reactivation of latent HCMV or that reactivation of latent HCMV could precipitate progression to TB disease.

\section{Epidemiological convergence}

Both Mtb and HCMV infections are ubiquitous ${ }^{1,33}$, and during millions of years of co-evolution have become highly human host-specific ${ }^{34-36}$. An animal reservoir has been described for neither Mtb nor HCMV (several monkey and rodent species have their distinct CMV species), implying that their epidemiological patterns are entirely determined by transmission between, and carriage by, humans.

We hypothesize that immunologically active HCMV infection, whether primary, reactivation or re-infection, acts as (depending on one's preferred framework) second-hit or precipitating 
factor for progression of latent $\mathrm{TB}$ infection to $\mathrm{TB}$ disease at an epidemiologically relevant scale. We base this on two arguments: their striking similarity in age distribution, and the existence of congruent risk factors [Box 1].

\section{Box 1. Approach to evidence gathering}

We systematically searched PubMed for the following combinations of keywords: tuberculosis and cytomegalovirus; cytomegalovirus and prevalence or seroprevalence; cytomegalovirus and age; cytomegalovirus and reinfection; cytomegalovirus and sexual; tuberculosis and sexual; tuberculosis and sexual transmitted infections or Chlamydia or gonorrhoea or human papillomavirus; tuberculosis and blood transfusion; cytomegalovirus and blood transfusion; tuberculosis and gastrectomy; cytomegalovirus and renal dialysis; tuberculosis and renal dialysis; tuberculosis and organ transplantation; cytomegalovirus and organ transplantation.

We in addition made use of an extensive review of the literature on age-sex distribution of tuberculosis incidence published by Nagelkerke $(2012)^{37}$

\section{Age distribution}

The probability of progressing from TB infection to disease has a highly typical age distribution. The classical description of this age pattern is by Comstock et al, who followed 82,269 Puerto Rican children reacting to tuberculin enrolled in 1949-1951 for 8 to 20 years [Figure 1$]^{38}$. This pattern, confirmed in a systematic review of studies from the pre-chemotherapy era ${ }^{39}$, is defined by a peak in the first 1-4 years of life, followed by a trough until early puberty, rising to a second peak around the age of 20 years. Analyses of notification and prevalence data from high-incidence countries show that incidence starts to rise again from the sixth decade ${ }^{40,41}$. Although several explanations for this age pattern have been suggested, none has been proven.

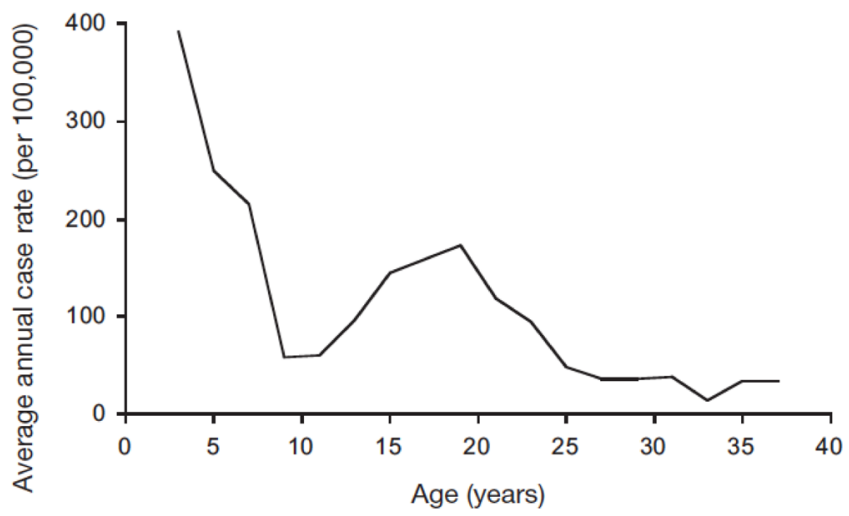

Figure 1. Age-specific incidence of tuberculosis disease among tuberculin-reactive children. Average annual rate of tuberculosis disease in a cohort of 82,269 Puerto Rican children with a positive tuberculin skin test, by age of disease occurrence. Children were enrolled in the period 1949-1951, and followed for 8 to 20 years. Figure reproduced with permission from Comstock et al. (1974) ${ }^{38}$.
Infants. Studies from the pre-chemotherapy era showed that, while the risk of infection with Mtb in the first year of life was over 10-fold lower than later in childhood, the risk of progression to disease once infected was much higher with up to $50 \%$ of infected infants developing disease ${ }^{39}$. These high progression rates have been attributed to age-specific maturation of immune responses ${ }^{42}$, although the mechanisms responsible for this vulnerability have not been elucidated ${ }^{43}$.

HCMV infection in infants is common ${ }^{44}$. Depending on the country and socio-economic status of the mother, between 10 and $60 \%$ of children are HCMV IgG seropositive (reflecting current or past active infection) by the age of 12-36 months ${ }^{45-52}$. Important causes are congenital infection and transmission through breastfeeding; $>85 \%$ of HCMV seropositive women excrete virus in the breastmilk ${ }^{44,53-56}$. Infants infected through breastfeeding do not develop disease, probably due to protection by maternal antibodies, but do shed virus in saliva and urine intermittently for months, by which they may transmit HCMV to other children and caregivers ${ }^{23,44,48,57}$. Shedding of HCMV shows a steep decline by the age of 5 years $^{23}$, coinciding with the age at which TB incidences drop ${ }^{38,39}$.

Adolescents. The rate of progression to TB disease then remains low until puberty. Several studies have observed an increase in TB incidence from this age onward among children who were exposed to infectious TB patients or had a positive tuberculin response, leading to a peak in incidence in the first half of the third decade ${ }^{38,58-63}$. This phenomenon has been attributed to hormonal changes, but again without a putative mechanistic pathway ${ }^{64}$.

Most population-based studies of HCMV seroprevalence show exactly this age pattern: a slow increase in HCMV IgG seroprevalence up to the age of 10-15 years, followed by an acceleration during adolescence ${ }^{45,47-50,52,65-72}$. One explanation for this increase in seroprevalence is sexual transmission. Various studies found that HCMV conversion among women was associated with sexual activity ${ }^{73-77}$. However, as several studies of adolescents found no association of HCMV seroprevalence with sexual exposure ${ }^{67,78,79}$, other transmission routes such as mouth-to-mouth kissing may also be important.

Another indication that HCMV infection may be implicated is the sex difference in $\mathrm{TB}$ disease progression in the second decade. For girls the increase in TB incidence starts 2-4 years earlier than for boys, and progression rates tend to remain higher in women than in men for the subsequent two decades, a pattern that was observed before the HIV era in various populations ${ }^{38,59,60,62,63,80-83}$. This pattern is again reflected in that of HCMV infection. The acceleration of HCMV seroprevalence during puberty and adolescence is steeper in girls than in boys and is higher in women of childbearing age than in men in populations with relatively low HCMV seroprevalence ${ }^{33,48,49,68,84-86}$. Age-adjusted HCMV seroprevalence does not differ between men and women in populations with high seroprevalence ${ }^{33,87}$. This may be because IgG seroprevalence measures cumulative infection experience and 
thus ignores reinfection. HCMV reinfection, identified by DNA typing or strain-specific antibody responses, is a common occurrence in sexually exposed women ${ }^{88-90}$.

Elderly. Although there is little data on TB progression rates in the elderly, age patterns of TB notifications suggest increased progression rates from the sixth decade onward ${ }^{1,40}$. In populations with declining incidence rates over the past decades this is partially a cohort effect, whereby younger generations have lower prevalence of latent infection ${ }^{91,92}$. However in high-incidence countries with little change in TB incidence, notification rates clearly increase at older age ${ }^{1}$. This is also observed for TB prevalence in population surveys, suggesting that this is not explained by better access to diagnosis ${ }^{1}$. HCMV infection has been implicated as a cause of age-related decrease in naïve $\mathrm{T}$ cells and increase in memory $\mathrm{T}$ cells known as immunosenescence ${ }^{93}$. However, reactivation of HCMV infection is also common at old age, probably reflecting weakening immune control ${ }^{29}$. Detection of viral DNA increases after the age of $60-70$ years ${ }^{94,95}$, and viral DNA is frequently detected in urine and plasma of elderly people ${ }^{96,97}$.

\section{Congruent risk factors}

Our hypothesis predicts that factors that drive CMV (re-)infection are also risk factors for TB. We highlight the four most important: socio-economic status, sexual contact, blood transfusion, and solid organ transplantation.

Socio-economic status. Incidence and prevalence of CMV infection are associated with poor socio-economic status (SES), between countries as well as within countries and communities $^{33,48,49,84,98-100}$. This includes association with crowding, in particular the number of young children in household ${ }^{101-103}$. Several studies found ethnicity or migrant status to be independently associated with age-adjusted CMV prevalence ${ }^{49,68,104}$, which may partly reflect higher background infection rates in the country of origin. In a US study the association with ethnicity was explained by differences in exposure to infants and sexual risk $^{77}$.

Also the incidence of TB, often regarded as the archetypal poverty disease, shows a remarkable inverse gradient with SES at the household, regional and country level ${ }^{105-107}$. This association has been explained mainly by crowding in ill-ventilated spaces conducive to Mtb transmission ${ }^{108}$, poor nutritional status ${ }^{12,109}$, alcohol abuse $\mathrm{e}^{15}$ and, possibly, indoor air pollution ${ }^{110}$. Similarly, in low-incidence countries, TB incidences are higher in particular ethnic groups and immigrants ${ }^{11,112}$, which also may reflect socio-economic disparities and differences in background infection rates ${ }^{113}$. Very few studies have attempted to investigate whether these and other known risk factors explain all of the observed variation in SES-related TB incidence ${ }^{114}$.

Sexual contact. The risk of CMV (re-)infection in adults is correlated with measures of sexual activity such as age at first intercourse, recent and lifetime number of sexual partners and condom use, as well as with prevalence of other sexually transmitted infections $\mathrm{s}^{73,74,76,115-117}$. Historically, TB has also been associated with sexual promiscuity in medical and popular literature (reviewed in 37) but no systematic epidemiological data exist. Investigation of associations between TB disease and sexually transmitted infections has been strongly dominated by HIV infection, which may obviously be a major confounder. There have been few studies from low HIV prevalence populations. One from China found an association between history of TB and human papilloma virus infection $^{118}$.

Interestingly, the declining TB mortality rates in The Netherlands and England and Wales in the $20^{\text {th }}$ century showed no surge during the Great Depression ${ }^{105,119}$, when SES status deteriorated thereby affecting several of these known risk factors, in particular nutritional status. They did however surge during and shortly after the Second World War ${ }^{105,119}$. In England and Wales this was not paralleled by major deterioration in nutritional status; in The Netherlands famine only started in the winter of 1944-45 while the increase in TB mortality started already from $1942^{37}$. In both countries during this period major increases were seen in sexually transmitted infections, mainly related to presence of large numbers of Allied and Axis troops ${ }^{37}$.

Blood transfusion. Transfusion-associated CMV infection occurs in particular following multiple transfusions of whole blood or granulocytes, and can be prevented by removal of white blood cells ${ }^{120-122}$. Increased incidences of TB have indeed been described in two categories of patients who in the past often received multiple whole blood transfusions: patients who underwent (partial) gastrectomy, mainly for bleeding gastric ulcers ${ }^{123,124}$, and patients with end-stage renal disease on haemodialysis ${ }^{125}$. For both these categories alternative explanations for increased TB incidences are possible: low body mass index for gastrectomy ${ }^{123,124}$, and impaired cellular immunity due to uraemia for haemodialysis ${ }^{126}$. Nonetheless, several studies among haemodialysis patients have suggested increased rates of CMV (re)infection, either or not associated with transfusion of blood or blood products ${ }^{127-131}$, as well as increased rates of CMV reactivation ${ }^{127}$.

Solid organ transplantation. The incidence of symptomatic CMV infection is strongly increased in solid organ transplant patients, mainly due to infection from a CMV IgG positive donor $^{132}$. Solid organ transplantation also increases the risk of TB disease ${ }^{125,133-135}$. TB incidence is highest in lung transplant patients and associated with presence of latent TB infection, clinical condition and intensity of the immunosuppressive therapy; the latter has been brought forward as the sole explanation for the increased TB risk ${ }^{136}$. Interestingly, a study among Korean solid organ transplant patients found that the risk of developing TB was associated with CMV infection within the prior 3 months ${ }^{137}$.

\section{Potential impact on tuberculosis control and elimination}

If indeed CMV (re-)infection or reactivation commonly precipitates progression from latent infection to active TB, this will 
suggest novel approaches to TB control. Combining a test for Mtb infection with one for ongoing or recent active CMV infection may strongly increase our ability to predict the development of TB disease and allow the targeting of preventive treatment to those most at risk $^{4}$. Vaccination against $\mathrm{CMV}$ might prevent $\mathrm{TB}$ in those with $\mathrm{TB}$ infection. A wide range of CMV vaccines are currently in clinical development including plasmid-based vaccines, viral vector vaccines, attenuated HCMV strains, and recombinant protein and peptide vaccines ${ }^{138}$. Recently, a genetically modified CMV vector expressing antigens from Mtb (RhCMV/TB) has shown 41\% sterile protection against $\mathrm{Mtb}$ in a non-human primate $\mathrm{study}^{139}$. If the human version of this vaccine was able to afford (partial) protection against CMV, it could also significantly impact the TB epidemic. CMV infection may also affect $\mathrm{TB}$ treatment response, another potential application therefore could be the provision of CMV antiviral treatment as an adjunct to TB treatment, for example of patients with multidrug resistance.

\section{Future research}

There is an urgent need for elucidating the role of CMV infection in TB disease progression. Further serological and cellular studies should be done to confirm the association between TB disease and CMV infection. However, in settings with high CMV seroprevalence (also those with highest TB incidence) it will be important to identify recent reinfection for which various diagnostic approaches exist ${ }^{22}$. Their relative merits are beyond the scope of this article, but some may potentially signal reactivation due to Mtb replication, i.e. consequence rather than cause. Therefore, ultimately longitudinal studies are needed in which the incidence of TB disease among those with latent TB infection is measured over time comparing those with CMV (re-)infection or reactivation to those without. These studies should be supplemented with immunological studies to define the mechanisms through which CMV precipitates progression to active TB disease. Finally, it will be important to study the role of CMV reactivation during $\mathrm{TB}$ disease and its effect on the response to TB treatment.

\section{Competing interests}

No competing interests were disclosed.

\section{Grant information}

The author(s) declared that no grants were involved in supporting this work.
1. WHO | Global tuberculosis report 2017. WHO: Geneva, 2017. Reference Source

2. Ferebee $\mathrm{SH}$ : Controlled chemoprophylaxis trials in tuberculosis. A general review. Bibl Tuberc. 1970; 26: 28-106. PubMed Abstract

3. Dheda K, Barry CE 3rd, Maartens G: Tuberculosis. Lancet. 2016; 387(10024): 1211-26.

PubMed Abstract | Publisher Full Text

4. Cobelens $\mathrm{F}$, Kik S, Esmail $\mathrm{H}$, et al.: From latent to patent: rethinking prediction of tuberculosis. Lancet Respir Med. 2017; 5(4): 243-4. PubMed Abstract | Publisher Full Text

5. Muller J, Matsumiya M, Snowden MA, et al.: Cytomegalovirus infection is a risk factor for TB disease in Infants. bioRxiv. 2017; 222646. Publisher Full Text

6. Garcia-Knight MA, Nduati E, Hassan AS, et al:: Cytomegalovirus viraemia is associated with poor growth and T-cell activation with an increased burden in HIV-exposed uninfected infants. AIDS. 2017; 31(13): 1809-18. PubMed Abstract | Publisher Full Text | Free Full Text

7. Miles DJ, van der Sande M, Jeffries D, et al:: Cytomegalovirus infection in Gambian infants leads to profound CD8 T-cell differentiation. J Virol. 2007; 81(11): $5766-76$

PubMed Abstract | Publisher Full Text | Free Full Text

8. Olaleye OD, Omilabu SA, Baba SS: Cytomegalovirus infection among tuberculosis patients in a chest hospital in Nigeria. Comp Immunol Microbiol Infect Dis. 1990; 13(2): 101-6.

PubMed Abstract | Publisher Full Text

9. Sirenko IA, Shmat'ko SA, Smelianskaia MV, et al:: [Impact of cytomegalovirus infection on the course of tuberculosis in children and adolescents]. Probl Tuberk Bolezn Legk. 2003; (8): 7-9. PubMed Abstract

10. Stockdale L, Nash S, Nalwoga A, et al.: Human cytomegalovirus epidemiology and relationship to tuberculosis and cardiovascular disease risk factors in a rural Ugandan cohort. PLoS One. 2018; 13(2): e0192086. PubMed Abstract | Publisher Full Text | Free Full Text

11. Comstock GW: Tuberculosis--a bridge to chronic disease epidemiology Am J Epidemiol. 1986; 124(1): 1-16. PubMed Abstract | Publisher Full Text
12. Lönnroth $\mathrm{K}$, Williams BG, Cegielski $\mathrm{P}$, et al:: A consistent log-linear relationship between tuberculosis incidence and body mass index. Int J Epidemiol. 2010; 39(1): 149-55

PubMed Abstract | Publisher Full Text

13. Jeon $\mathrm{CY}$, Murray MB: Diabetes mellitus increases the risk of active tuberculosis: a systematic review of 13 observational studies. PLoS Med. 2008; 5(7): e152.

PubMed Abstract | Publisher Full Text | Free Full Text

14. Lin HH, Ezzati M, Murray M: Tobacco smoke, indoor air pollution and tuberculosis: a systematic review and meta-analysis. PLOS Med. 2007; 4(1): e20. PubMed Abstract | Publisher Full Text | Free Full Text

15. Lönnroth K, Williams BG, Stadlin S, et al.: Alcohol use as a risk factor for tuberculosis - a systematic review. BMC Public Health. 2008; 8: 289. PublMed Abstract | Publisher Full Text | Free Full Text

16. Esmail H, Barry CE Jr, Young DB, et al:: The ongoing challenge of latent tuberculosis. Philos Trans R Soc Lond B Biol Sci. 2014; 369(1645): 20130437. PubMed Abstract | Publisher Full Text | Free Full Text

17. Redford PS, Mayer-Barber KD, McNab FW, et al:: Influenza A virus impairs control of Mycobacterium tuberculosis coinfection through a type I interferon receptor-dependent pathway. J Infect Dis. 2014; 209(2): 270-4. PubMed Abstract | Publisher Full Text | Free Full Text

18. Fares A: Seasonality of Tuberculosis. J Glob Infect Dis. 2011; 3(1): 46-55. PubMed Abstract | Publisher Full Text | Free Full Text

19. Walaza S, Cohen C, Nanoo A, et al.: Excess Mortality Associated with Influenza among Tuberculosis Deaths in South Africa, 1999-2009. PLoS One. 2015; 10(6): e0129173.

PubMed Abstract | Publisher Full Text | Free Full Text

20. Zürcher K, Zwahlen M, Ballif M, et al.: Influenza Pandemics and Tuberculosis Mortality in 1889 and 1918: Analysis of Historical Data from Switzerland. PLoS One. 2016; 11(10): e0162575.

PubMed Abstract | Publisher Full Text | Free Full Text

21. Tedijanto C, Hermans S, Cobelens F, et al:: Drivers of seasonal variation in tuberculosis incidence: insights from a systematic review and mathematical model. Epidemiology. in press.

22. Dioverti MV, Razonable RR: Cytomegalovirus. Microbiol Spectr. 2016; 4(4). PubMed Abstract | Publisher Full Text

23. Cannon MJ, Hyde TB, Schmid DS: Review of cytomegalovirus shedding in 
bodily fluids and relevance to congenital cytomegalovirus infection. Rev Med Virol. 2011; 21(4): 240-55

PubMed Abstract | Publisher Full Text | Free Full Text

24. Chou S: Comparative analysis of sequence variation in gp116 and gp55 components of glycoprotein B of human cytomegalovirus. Virology. 1992; 188(1): 388-90.

PubMed Abstract | Publisher Full Text

25. Pignatelli S, Dal Monte P, Landini MP: gpUL73 $(\mathbf{g N})$ genomic variants of human cytomegalovirus isolates are clustered into four distinct genotypes. $J$ Gen Virol. 2001; 82(Pt 11): 2777-84

PubMed Abstract | Publisher Full Text

26. Leach CT, Detels R, Hennessey $\mathrm{K}$, et al:: A longitudinal study of cytomegalovirus infection in human immunodeficiency virus type 1-seropositive homosexual men: molecular epidemiology and association with disease progression. $J$ Infect Dis. 1994; 170(2): 293-8.

PubMed Abstract | Publisher Full Text

27. Novak Z, Ross SA, Patro RK, et al:: Cytomegalovirus strain diversity in seropositive women. J Clin Microbiol. 2008; 46(3): 882-6. PubMed Abstract | Publisher Full Text | Free Full Text

28. Bale JF Jr, Petheram SJ, Souza IE, et al.: Cytomegalovirus reinfection in young children. J Pediatr. 1996; 128(3): 347-52. PubMed Abstract | Publisher Full Text

29. Jackson SE, Redeker A, Arens R, et al:: CMV immune evasion and manipulation of the immune system with aging. GeroScience. 2017; 39(3): 273-91. PubMed Abstract | Publisher Full Text | Free Full Text

30. Goodier MR, Jonjić S, Riley EM, et al.: CMV and natural killer cells: shaping the response to vaccination. Eur J Immunol. 2018; 48(1): 50-65.

PubMed Abstract | Publisher Full Text

31. Brinkmann MM, Dağ F, Hengel $\mathrm{H}$, et al:: Cytomegalovirus immune evasion of myeloid lineage cells. Med Microbiol Immunol. 2015; 204(3): 367-82. PubMed Abstract | Publisher Full Text

32. Balthesen M, Messerle M, Reddehase MJ: Lungs are a major organ site of cytomegalovirus latency and recurrence. J Virol. 1993; 67(9): 5360-6. PubMed Abstract | Free Full Text

33. Cannon MJ, Schmid DS, Hyde TB: Review of cytomegalovirus seroprevalence and demographic characteristics associated with infection. Rev Med Virol. 2010; 20(4): 202-13.

PubMed Abstract | Publisher Full Text

34. Brosch R, Gordon SV, Marmiesse M, et al:: A new evolutionary scenario for the Mycobacterium tuberculosis complex. Proc Natl Acad Sci U S A. 2002; 99(6): 3684-9.

PubMed Abstract | Publisher Full Text | Free Full Text

35. Gutierrez MC, Brisse S, Brosch R, et al:: Ancient origin and gene mosaicism of the progenitor of Mycobacterium tuberculosis. PLoS Pathog. 2005; 1(1): e5. PubMed Abstract | Publisher Full Text | Free Full Text

36. Reddehase MJ: The immunogenicity of human and murine cytomegaloviruses. Curr Opin Immunol. 2000; 12(4): 390-6.

PubMed Abstract | Publisher Full Text

37. Nagelkerke NJ: Courtesans and consumption. How sexually transmitted infections drive tuberculosis epidemics. Delft: Eburon, 2012. Reference Source

38. Comstock GW, Livesay VT, Woolpert SF: The prognosis of a positive tuberculin reaction in childhood and adolescence. Am J Epidemiol. 1974; 99(2): 131-8. PubMed Abstract | Publisher Full Text

39. Marais BJ, Gie RP, Schaaf HS, et al.: The natural history of childhood intrathoracic tuberculosis: a critical review of literature from the pre-chemotherapy era. Int J Tuberc Lung Dis. 2004; 8(4): 392-402. PubMed Abstract

40. Stead WW, Lofgren JP: Does the risk of tuberculosis increase in old age? $J$ Infect Dis. 1983; 147(5): 951-5.

PubMed Abstract

41. Onozaki I, Law I, Sismanidis C, et al.: National tuberculosis prevalence surveys in Asia, 1990-2012: an overview of results and lessons learned. Trop Med Int Health. 2015; 20(9): 1128-45.

PubMed Abstract | Publisher Full Text

42. Schaaf HS, Collins A, Bekker A, et al:: Tuberculosis at extremes of age Respirology. 2010; 15(5): 747-63. PubMed Abstract | Publisher Full Text

43. Vanden Driessche K, Persson A, Marais BJ, et al.: Immune vulnerability of infants to tuberculosis. Clin Dev Immunol. 2013; 2013: 781320. PubMed Abstract | Publisher Full Text | Free Full Text

44. Pass RF, Anderson B: Mother-to-Child Transmission of Cytomegalovirus and Prevention of Congenital Infection. J Pediatr Infect Dis Soc. 2014; 3 Suppl 1: S2-6.

PubMed Abstract | Publisher Full Text | Free Full Text

45. Liu Z, Wang E, Taylor W, et al:: Prevalence survey of cytomegalovirus infection in children in Chengdu. Am J Epidemiol. 1990; 131(1): 143-50.

PubMed Abstract | Publisher Full Text

46. Natali A, Valcavi P, Medici MC, et al.: Cytomegalovirus infection in an Italian population: antibody prevalence, virus excretion and maternal transmission. New Microbiol. 1997; 20(2): 123-33.

PubMed Abstract
47. Lanzieri TM, Kruszon-Moran D, Amin MM, et al:: Seroprevalence of cytomegalovirus among children 1 to 5 years of age in the United States from the National Health and Nutrition Examination Survey of 2011 to 2012. Clin Vaccine Immunol. 2015; 22(2): 245-7.

PubMed Abstract | Publisher Full Text | Free Full Text

48. Voigt S, Schaffrath Rosario A, Mankertz A: Cytomegalovirus Seroprevalence Among Children and Adolescents in Germany: Data From the German Health Interview and Examination Survey for Children and Adolescents (KiGGS), 2003-2006. Open Forum Infect Dis. 2016; 3(1): ofv193. PubMed Abstract | Publisher Full Text | Free Full Text

49. Korndewal MJ, Mollema L, Tcherniaeva I, et al:: Cytomegalovirus infection in the Netherlands: seroprevalence, risk factors, and implications. J Clin Virol. 2015; 63: 53-8.

PubMed Abstract | Publisher Full Text

50. Fang FQ, Fan QS, Yang ZJ, et al.: Incidence of cytomegalovirus infection in Shanghai, China. Clin Vaccine Immunol. 2009; 16(11): 1700-3.

PubMed Abstract | Publisher Full Text | Free Full Text

51. O'Brien TP, Thompson JM, Black PN, et al:: Prevalence and determinants of cytomegalovirus infection in pre-school children. J Paediatr Child Health. 2009; 45(5): 291-6.

PubMed Abstract | Publisher Full Text

52. Seale $\mathrm{H}$, Maclntyre $\mathrm{CR}$, Gidding HF, et al.: National serosurvey of cytomegalovirus in Australia. Clin Vaccine Immunol. 2006; 13(11): 1181-4. PubMed Abstract | Publisher Full Text | Free Full Text

53. Stagno S, Reynolds DW, Pass RF, et al.: Breast milk and the risk of cytomegalovirus infection. N Engl J Med. 1980; 302(19): 1073-6. PubMed Abstract | Publisher Full Text

54. Hotsubo T, Nagata N, Shimada M, et al.: Detection of human cytomegalovirus DNA in breast milk by means of polymerase chain reaction. Microbiol Immunol. 1994; 38(10): 809-11.

PubMed Abstract | Publisher Full Tex

55. Vochem M, Hamprecht K, Jahn G, et al.: Transmission of cytomegalovirus to preterm infants through breast milk. Pediatr Infect Dis J. 1998; 17(1): 53-8. PubMed Abstract

56. Hamprecht K, Maschmann J, Vochem M, et al.: Epidemiology of transmission of cytomegalovirus from mother to preterm infant by breastfeeding. Lancet. 2001; 357(9255): 513-8

PubMed Abstract | Publisher Full Text

57. Cannon MJ, Stowell JD, Clark R, et al:: Repeated measures study of weekly and daily cytomegalovirus shedding patterns in saliva and urine of healthy cytomegalovirus-seropositive children. BMC Infect Dis. 2014; 14: 569. PubMed Abstract | Publisher Full Text | Free Full Text

58. Pope AS, Sartwell PE, Zacks D: Development of Tuberculosis in Infected Children. Am J Public Health Nations Health. 1939; 29(12): 1318-25. PubMed Abstract | Free Full Text

59. Zeidberg LD, Dillon A: Risk of developing tuberculosis among children of tuberculous parents. Am Rev Tuberc. 1954; 70(6): 1009-19. PubMed Abstract

60. Zeidberg LD, Gass RS, Dillon A et al: The Williamson County Tuberculosis Study. A twenty-four-year epidemiologic study. Am Rev Respir Dis. 1963; 87((3) Pt 2): $1-88$ PubMed Abstract

61. BCG and vole bacillus vaccines in the prevention of tuberculosis in adolescence and early adult life. Bull World Health Organ. 1972; 46(3): 371-85. PubMed Abstract | Free Full Text

62. Tuberculosis in a rural population of South India: a five-year epidemiological study. Bull World Health Organ. 1974; 51(5): 473-88. PubMed Abstract | Free Full Text

63. Comstock GW, Ferebee SH, Hammes LM: A controlled trial of communitywide isoniazid prophylaxis in Alaska. Am Rev Respir Dis. 1967; 95(6): 935-43. PubMed Abstract

64. Horton KC, MacPherson P, Houben RM, et al:: Sex Differences in Tuberculosis Burden and Notifications in Low- and Middle-Income Countries: A Systematic Review and Meta-analysis. PLoS Med. 2016; 13(9): e1002119. PubMed Abstract | Publisher Full Text | Free Full Text

65. Vyse AJ, Hesketh LM, Pebody RG: The burden of infection with cytomegalovirus in England and Wales: how many women are infected in pregnancy? Epidemiol Infect. 2009; 137(4): 526-33.

PubMed Abstract | Publisher Full Text

66. Lopo S, Vinagre E, Palminha $P$, et al:: Seroprevalence to cytomegalovirus in the Portuguese population, 2002-2003. Euro Surveill. 2011; 16(25): pii: 19896. PubMed Abstract

67. Stadler LP, Bernstein DI, Callahan ST, et al:: Seroprevalence of cytomegalovirus (CMV) and risk factors for infection in adolescent males. Clin Infect Dis. 2010; 51(10): e76-81.

PubMed Abstract | Publisher Full Text | Free Full Text

68. Bate SL, Dollard SC, Cannon MJ: Cytomegalovirus seroprevalence in the United States: the national health and nutrition examination surveys, 1988-2004. Clin Infect Dis. 2010; 50(11): 1439-47. PubMed Abstract | Publisher Full Text

69. Dowd JB, Aiello AE, Alley DE: Socioeconomic disparities in the seroprevalence of cytomegalovirus infection in the US population: NHANES III. Epidemiol 
Infect. 2009; 137(1): 58-65.

PubMed Abstract | Publisher Full Text | Free Full Text

70. Staras SA, Dollard SC, Radford KW, et al:: Seroprevalence of cytomegalovirus infection in the United States, 1988-1994. Clin Infect Dis. 2006; 43(9): 1143-51. PubMed Abstract | Publisher Full Text

71. Aarnisalo J, Ilonen J, Vainionpää R, et al.: Development of antibodies against cytomegalovirus, varicella-zoster virus and herpes simplex virus in Finland during the first eight years of life: a prospective study. Scand J Infect Dis. 2003, 35(10): $750-3$

PubMed Abstract | Publisher Full Text

72. Almeida LN, Azevedo RS, Amaku M, et al:: Cytomegalovirus seroepidemiology in an urban community of São Paulo, Brazil. Rev Saude Publica. 2001; 35(2): $124-9$.

PubMed Abstract | Publisher Full Text

73. Coonrod D, Collier AC, Ashley R, et al.: Association between cytomegalovirus seroconversion and upper genital tract infection among women attending a sexually transmitted disease clinic: a prospective study. J Infect Dis. 1998; 177(5): 1188-93.

PubMed Abstract | Publisher Full Text

74. Collier $\mathrm{AC}$, Handsfield $\mathrm{HH}$, Roberts $\mathrm{PL}$, et al:: Cytomegalovirus infection in women attending a sexually transmitted disease clinic. J Infect Dis. 1990; 162(1): 46-51.

PubMed Abstract | Publisher Full Text

75. Francisse $\mathrm{S}$, Revelard $\mathrm{P}$, De Maertelaer $\mathrm{V}$, et al:: Human cytomegalovirus seroprevalence and risk of seroconversion in a fertility clinic population. Obstet Gynecol. 2009; 114(2 Pt 1): 285-91.

PubMed Abstract | Publisher Full Text

76. Staras SA, Flanders WD, Dollard SC, et al.: Influence of sexual activity on cytomegalovirus seroprevalence in the United States, 1988-1994. Sex Transm Dis. 2008; 35(5): 472-9.

PubMed Abstract | Publisher Full Text

77. Lanzieri TM, Kruszon-Moran D, Gambhir M, et al.: Influence of parity and sexual history on cytomegalovirus seroprevalence among women aged 20-49 years in the USA. Int J Gynaecol Obstet. 2016; 135(1): 82-5. PubMed Abstract | Publisher Full Text | Free Full Text

78. Patrick EJ, Higgins $\mathrm{CD}$, Crawford $\mathrm{DH}$, et al:: A cohort study in university students: investigation of risk factors for cytomegalovirus infection. Epidemio Infect. 2014; 142(9): 1990-5.

PubMed Abstract | Publisher Full Text

79. Foxworth MK 2nd, Wilms IR, Brookman RR, et al:: Prevalence of CMV infection among sexually active adolescents: a matched case-control study. Adolesc Health Med Ther. 2014; 5: 73-8.

PubMed Abstract | Publisher Full Text | Free Full Text

80. Frost $\mathrm{WH}$ : The age selection of mortality from tuberculosis in successive decades. 1939. Am J Epidemiol. 1995; 141(1): 4-9; discussion 3. PubMed Abstract

81. Grzybowski S, Allen EA: The Challenge Of Tuberculosis In Decline. A Study Based On The Epidemiology Of Tuberculosis In Ontario, Canada. Am Rev Respir Dis. 1964; 90: 707-20. PubMed Abstract

82. Groth-Petersen E, Knudsen J, Wilbek E: Epidemiological basis of tuberculosis eradication in an advanced country. Bull World Health Organ. 1959; 21: 5-49. PubMed Abstract | Free Full Text

83. Comstock GW, Edwards PQ: The competing risks of tuberculosis and hepatitis for adult tuberculin reactors. Am Rev Respir Dis. 1975; 111(5): 573-7. PubMed Abstract

84. Ibrahim S, Siddiqui AA, Siddiqui AR, et al:: Sociodemographic factors associated with IgG and IgM seroprevalence for human cytomegalovirus infection in adult populations of Pakistan: a seroprevalence survey. BMC Public Health. 2016; 16(1): 1112

PubMed Abstract | Publisher Full Text | Free Full Text

85. Antona D, Lepoutre A, Fonteneau L, et al:: Seroprevalence of cytomegalovirus infection in France in 2010. Epidemiol Infect. 2017; 145(7): 1471-8. PubMed Abstract | Publisher Full Text

86. Badami KG, McQuilkan-Bickerstaffe S, Wells JE, et al:: Cytomegalovirus seroprevalence and 'cytomegalovirus-safe' seropositive blood donors. Epidemiol Infect. 2009; 137(12): 1776-80. PubMed Abstract | Publisher Full Tex

87. Conde-Glez C, Lazcano-Ponce E, Rojas R, et al.: Seroprevalences of varicellazoster virus, herpes simplex virus and cytomegalovirus in a cross-sectiona study in Mexico. Vaccine. 2013; 31(44): 5067-74.

PubMed Abstract | Publisher Full Text

88. Chandler $\mathrm{SH}$, Handsfield HH, McDougall JK: Isolation of multiple strains of cytomegalovirus from women attending a clinic for sexually transmitted disease. J Infect Dis. 1987; 155(4): 655-60. PubMed Abstract | Publisher Full Tex

89. Boppana SB, Rivera LB, Fowler KB, et al.: Intrauterine transmission of cytomegalovirus to infants of women with preconceptional immunity. N Engl J Med. 2001; 344(18): 1366-71. PubMed Abstract | Publisher Full Text

90. Yamamoto AY, Mussi-Pinhata MM, Boppana SB, et al.: Human cytomegalovirus reinfection is associated with intrauterine transmission in a highly cytomegalovirus-immune maternal population. Am J Obstet Gynecol. 2010;
202(3): 297.e1-8.

PubMed Abstract | Publisher Full Text

91. Hinman AR, Judd JM, Kolnik JP, et al:: Changing risks in tuberculosis. Am J Epidemiol. 1976; 103(5): 486-97. PubMed Abstract | Publisher Full Text

92. Raviglione MC, Sudre P, Rieder HL, et al:: Secular trends of tuberculosis in western Europe. Bull World Health Organ. 1993; 71(3-4): 297-306. PubMed Abstract | Free Full Text

93. Weltevrede M, Eilers R, de Melker HE, et al:: Cytomegalovirus persistence and T-cell immunosenescence in people aged fifty and older: A systematic review. Exp Gerontol. 2016; 77: 87-95.

PubMed Abstract | Publisher Full Text

94. Parry HM, Zuo J, Frumento G, et al:: Cytomegalovirus viral load within blood increases markedly in healthy people over the age of $\mathbf{7 0}$ years. Immun Ageing. 2016; 13: 1

PubMed Abstract | Publisher Full Text | Free Full Text

95. Furui $\mathrm{Y}$, Satake M, Hoshi $\mathrm{Y}$, et al:: Cytomegalovirus (CMV) seroprevalence in Japanese blood donors and high detection frequency of CMV DNA in elderly donors. Transfusion. 2013; 53(10): 2190-7.

PubMed Abstract | Publisher Full Text

96. Stowe RP, Kozlova EV, Yetman DL, et al:: Chronic herpesvirus reactivation occurs in aging. Exp Gerontol. 2007; 42(6): 563-70. PubMed Abstract | Publisher Full Text | Free Full Tex

97. Thomasini RL, Pereira DS, Pereira FSM, et al.: Aged-associated cytomegalovirus and Epstein-Barr virus reactivation and cytomegalovirus relationship with the frailty syndrome in older women. PLoS One. 2017; 12(7): e0180841. PubMed Abstract | Publisher Full Text | Free Full Text

98. Lantos PM, Hoffman K, Permar SR, et al:: Neighborhood Disadvantage is Associated with High Cytomegalovirus Seroprevalence in Pregnancy. $J$ Racial Ethn Health Disparities. 2017; 1-5.

PubMed Abstract | Publisher Full Text | Free Full Text

99. Enders G, Daiminger A, Lindemann L, et al:: Cytomegalovirus (CMV) seroprevalence in pregnant women, bone marrow donors and adolescents in Germany, 1996-2010. Med Microbiol Immunol. 2012; 201(3): 303-9. PubMed Abstract | Publisher Full Text

100. Wujcicka W, Gaj Z, Wilczyński J, et al.: Impact of socioeconomic risk factors on the seroprevalence of cytomegalovirus infections in a cohort of pregnant Polish women between 2010 and 2011. Eur J Clin Microbiol Infect Dis. 2014; 33(11): 1951-8. PubMed Abstract | Publisher Full Text | Free Full Text

101. Stadler LP, Bernstein DI, Callahan ST, et al: Seroprevalence and Risk Factors for Cytomegalovirus Infections in Adolescent Females. J Pediatr Infect Dis Soc. 2013; 2(1): 7-14

PubMed Abstract | Publisher Full Text | Free Full Text

102. Schmink S, Kruszon-Moran D, Dollard SC, Lanzieri TM: Effect of Breastfeeding and Additional Household Children on Cytomegalovirus Seroprevalence among U.S. Children 1 to 5 Years of Age. Clin Vaccine Immunol. 2017; 24(11): pii: e00243-17.

PubMed Abstract | Publisher Full Text | Free Full Text

103. Hannachi N, Marzouk M, Harrabi I, et al.: [Seroprevalence of rubella virus, varicella zoster virus, cytomegalovirus and parvovirus B19 among pregnant women in the Sousse region, Tunisia]. Bull Soc Pathol Exot. 2011; 104(1): 62-7. PubMed Abstract | Publisher Full Text

104. Jansen MA, van den Heuvel D, Bouthoorn SH, et al:: Determinants of Ethnic Differences in Cytomegalovirus, Epstein-Barr Virus, and Herpes Simplex Virus Type 1 Seroprevalence in Childhood. J Pediatr. 2016; 170: 126-134.e1-6. PubMed Abstract | Publisher Full Text

105. Lönnroth K, Jaramillo E, Williams BG, et al.: Drivers of tuberculosis epidemics: the role of risk factors and social determinants. Soc Sci Med. 2009; 68(12): 2240-6.

PubMed Abstract | Publisher Full Text

106. Hoa NB, Tiemersma EW, Sy DN, et al.: Household expenditure and tuberculosis prevalence in VietNam: prediction by a set of household indicators. Int $J$ Tuberc Lung Dis. 2011; 15(1): 32-7. PubMed Abstract

107. Janssens JP, Rieder HL: An ecological analysis of incidence of tuberculosis and per capita gross domestic product. Eur Respir J. 2008; 32(5): 1415-6. PubMed Abstract | Publisher Full Text

108. Chapman JS, Dyerly MD: Social and other factors in intrafamilial transmission of tuberculosis. Am Rev Respir Dis. 1964; 90: 48-60. PubMed Abstract

109. Cegielski JP, McMurray DN: The relationship between malnutrition and tuberculosis: evidence from studies in humans and experimental animals. Int J Tuberc Lung Dis. 2004; 8(3): 286-98. PubMed Abstract

110. Lin HH, Suk CW, Lo HL, et al.: Indoor air pollution from solid fuel and tuberculosis: a systematic review and meta-analysis. Int $J$ Tuberc Lung Dis. 2014; 18(5): 613-21. PubMed Abstract | Publisher Full Text

111. Scott C, Kirking HL, Jeffries C, et al:: Tuberculosis trends--United States, 2014. MMWR Morb Mortal Wkly Rep. 2015; 64(10): 265-9. PubMed Abstract | Free Full Text

112. Hollo V, Beauté J, Ködmön C, et al:: Tuberculosis notification rate decreases 
faster in residents of native origin than in residents of foreign origin in the EU/EEA, 2010 to 2015. Euro Surveill. 2017; 22(12): pii: 30486. PubMed Abstract | Publisher Full Text | Free Full Text

113. Cantwell MF, McKenna MT, McCray E, et al.: Tuberculosis and race/ethnicity in the United States: impact of socioeconomic status. Am J Respir Crit Care Med. 1998; 157(4 Pt 1): 1016-20.

PubMed Abstract | Publisher Full Text

114. Pedrazzoli D, Boccia D, Dodd PJ, et al.: Modelling the social and structural determinants of tuberculosis: opportunities and challenges. Int J Tuberc Lung Dis. 2017; 21(9): 957-64.

PubMed Abstract | Publisher Full Text | Free Full Text

115. Pereira LH, Embil JA, Haase DA, et al:: Cytomegalovirus infection among women attending a sexually transmitted disease clinic: association with clinical symptoms and other sexually transmitted diseases. Am J Epidemiol. 1990; 131(4): 683-92.

PubMed Abstract | Publisher Full Text

116. Fowler KB, Pass RF: Risk factors for congenital cytomegalovirus infection in the offspring of young women: exposure to young children and recent onset of sexual activity Pediatrics. 2006; 118(2): e286-292. PubMed Abstract | Publisher Full Text

117. Fowler $\mathrm{KB}, \mathrm{Ma} \mathrm{Y}$, Moscicki $\mathrm{B}$, et al:: Seroprevalence and risk factors of hepatitis $B$, hepatitis $C$, and human cytomegalovirus among HIV-infected and high-risk uninfected adolescents: findings of the REACH Study. Adolescent Medicine HIV/AIDS Research Network. Sex Transm Dis. 2000; 27(5): 296-303. PubMed Abstract | Publisher Full Text

118. Zhao FH, Forman MR, Belinson J, et al:: Risk factors for HPV infection and cervical cancer among unscreened women in a high-risk rural area of China. Int J Cancer. 2006; 118(2): 442-8. PubMed Abstract | Publisher Full Text

119. KNCV Tuberculosefonds: Tuberculose in Nederland. The Hague, 2008. Reference Source

120. Adler SP: Transfusion-associated cytomegalovirus infections. Rev Infect Dis. 1983; 5(6): 977-93

PubMed Abstract | Publisher Full Text

121. Forbes BA: Acquisition of cytomegalovirus infection: an update. Clin Microbiol Rev. 1989; 2(2): 204-16. PubMed Abstract | Publisher Full Text | Free Full Text

122. Pamphilon DH, Rider JR, Barbara JA, et al:: Prevention of transfusiontransmitted cytomegalovirus infection. Transfus Med. 1999; 9(2): 115-23. PubMed Abstract | Publisher Full Text

123. THORN PA, BROOKES VS, WATERHOUSE JA: Peptic ulcer, partial gastrectomy, and pulmonary tuberculosis. Br Med J. 1956; 1(4967): 603-8.

PubMed Abstract | Publisher Full Text | Free Full Text

124. Snider DE Jr: Tuberculosis and gastrectomy. Chest. 1985; 87(4): 414-5. PubMed Abstract

125. Al-Efraij K, Mota L, Lunny C, et al.: Risk of active tuberculosis in chronic kidney disease: a systematic review and meta-analysis. Int J Tuberc Lung Dis. 2015; 19(12): 1493-9.

PubMed Abstract | Publisher Full Text
126. Chou KJ, Fang HC, Bai KJ, et al.: Tuberculosis in maintenance dialysis patients. Nephron. 2001; 88(2): 138-43.

PubMed Abstract | Publisher Full Text

127. Hardiman $\mathrm{AE}$, Butter $\mathrm{KC}$, Roe $\mathrm{CJ}$, et al.: Cytomegalovirus infection in dialysis patients. Clin Nephrol. 1985; 23(1): 12-7. PubMed Abstract

128. Tolkoff-Rubin NA, Rubin RH, Keller EE, et al:: Cytomegalovirus infection in dialysis patients and personnel. Ann Intern Med. 1978; 89(5 Pt 1): 625-8. PubMed Abstract | Publisher Full Text

129. Vilibic-Cavlek T, Kolaric B, Beader N, et al:: Seroepidemiology of cytomegalovirus infections in Croatia. Wien Klin Wochenschr. 2017; 129(3-4): 129-35. PubMed Abstract | Publisher Full Text

130. Vilibic-Cavlek T, Kolaric B, Ljubin-Sternak S, et al.: Prevalence and dynamics of cytomegalovirus infection among patients undergoing chronic hemodialysis. Indian J Nephrol. 2015; 25(2): 95-8.

PubMed Abstract | Publisher Full Text | Free Full Text

131. Cantisán S, Rodelo-Haad C, Páez-Vega A, et al.: Factors related to the development of CMV-specific CD8+ T cell response in CMV-seropositive solid organ transplant candidates. Am J Transplant. 2015; 15(3): 715-22. PubMed Abstract | Publisher Full Text

132. Lumbreras $\mathrm{C}$, Manuel $\mathrm{O}$, Len $\mathrm{O}$, et al.: Cytomegalovirus infection in solid organ transplant recipients. Clin Microbiol Infect. 2014; 20 Suppl 7: 19-26. PubMed Abstract | Publisher Full Text

133. Ergun I, Ekmekci Y, Sengul S, et al:: Mycobacterium tuberculosis infection in renal transplant recipients. Transplant Proc. 2006; 38(5): 1344-5. PubMed Abstract | Publisher Full Text

134. Torre-Cisneros J, Doblas A, Aguado JM, et al.: Tuberculosis after solid-organ transplant: incidence, risk factors, and clinical characteristics in the RESITRA (Spanish Network of Infection in Transplantation) cohort. Clin Infect Dis. 2009; 48(12): $1657-65$.

PubMed Abstract | Publisher Full Text

135. Canet E, Dantal J, Blancho G, et al:: Tuberculosis following kidney transplantation: clinical features and outcome. A French multicentre experience in the last 20 years. Nephrol Dial Transplant. 2011; 26(11): 3773-8. PubMed Abstract | Publisher Full Text

136. Aguado JM, Torre-Cisneros J, Fortún J, et al:: Tuberculosis in solid-organ transplant recipients: consensus statement of the group for the study of infection in transplant recipients (GESITRA) of the Spanish Society of Infectious Diseases and Clinical Microbiology. Clin Infect Dis. 2009; 48(9): Infectious 1276-84

PubMed Abstract | Publisher Full Text

137. Ha YE, Joo EJ, Park SY, et al: Tacrolimus as a risk factor for tuberculosis and outcome of treatment with rifampicin in solid organ transplant recipients. Transpl Infect Dis. 2012; 14(6): 626-34. PubMed Abstract | Publisher Full Text

138. Anderholm KM, Bierle CJ, Schleiss MR: Cytomegalovirus Vaccines: Current Status and Future Prospects. Drugs. 2016; 76(17): 1625-45. PubMed Abstract | Publisher Full Text | Free Full Text

139. Hansen SG, Zak DE, Xu G, et al.: Prevention of tuberculosis in rhesus macaques by a cytomegalovirus-based vaccine. Nat Med. 2018; 24(2): 130-43. PubMed Abstract | Publisher Full Text 


\section{Open Peer Review}

\section{Current Peer Review Status:}

\section{Version 1}

Reviewer Report 22 March 2018

https://doi.org/10.5256/f1000research.15429.r32121

(C) 2018 Divangahi M. This is an open access peer review report distributed under the terms of the Creative Commons Attribution License, which permits unrestricted use, distribution, and reproduction in any medium, provided the original work is properly cited.

\section{Maziar Divangahi}

McGill Internation TB Center, University of McGill, Montréal, QC, Canada

Our continuous exposure to a multitude of pathogens requires a greater understanding of the host response to heterologous infections and is fundamental for developing novel therapies and vaccines against infectious diseases. In line with this, heterologous immunity to viruses and bacteria is an extremely complex scenario as our immune response greatly differs upon viral versus bacterial infection. Thus, how our immune system makes a balanced response to control both viral and bacterial infections without killing the host is a fascinating area of research.

In this review article, Cobelens and colleagues reviewed the available epidemiological data for human cytomegalovirus (HCMV) and Mycobacterium tuberculosis (Mtb) infections. The review is well written and provides interesting human observations that HCMV may contribute to the progression of latent TB to active disease. However, I have three major comments that potentially can improve the conceptual idea of the current review.

1) Type I IFN is a chief antiviral cytokine, which also plays a critical role in immunity to CMV infection (Plos Pathogens, 10:e1003962, 2014). However, it has been well documented that type I IFN increases host susceptibility to some bacterial infections including Francisella tularensis (V. Immunol. 169, 1665-1668, 2002), Listeria monocytogenes (J. Exp. Med. 185:921, 1997) and Mtb (J. Interferon Cytokine Res. 25:694, 2005 \& Nature, 511:99, 2014). This concept has been also supported by another recent study (JID, 290:270 2014) demonstrating influenza infection increased susceptibility to Mtb infection in a Type I IFN dependent manner. Although the authors briefly mention this idea, a cohesive expansion of this concept would provide further insight for the important role of type I IFN in viral infection and susceptibility to Mtb (Trends in Immunology, 36:307, 2015).

2) The authors need to be cautious about their conclusions regarding a recent paper using nonhuman primate (rhesus macaques) cytomegalovirus vectors encoding Mtb antigens (RhCMV/MTB) (Nature Medicine, 24:130, 2018) for the vaccine in TB. Although the protective data from this study are very impressive, the lack of cellular mechanism (e.g. the protection was independent of effector T cells) as well as the lack of several important controls including the 
empty vector (RhCMV) indicate that further investigations are required to have a better understanding of this approach as a vaccine in pre-clinical study prior to any human trial for TB.

3) The presented human observations that sexual contact and whole blood transfusion are the risk factors for tuberculosis is very speculative. Thus, the author should consider rephrasing this section at least in the abstract as it sounds very confirmative.

Minor comments:

1) The Age-specific death rates from TB in England and Wales was also reported for 1913 and 1918 that shows the same pattern (Table 2) and the authors may want to include this reference:

Langford, C. The age pattern of mortality in the 1918-1919 influenza pandemic: an attempted explanation based on data for England and Wales. Med. Hist. 46, 1-20 (2002).

2) As there is no evidence of Mtb activating latent HCMV in the lungs (Page 3), which is also not the focus of this review, the author may want to consider removing this entire paragraph.

Is the topic of the opinion article discussed accurately in the context of the current literature?

Yes

Are all factual statements correct and adequately supported by citations? Partly

Are arguments sufficiently supported by evidence from the published literature? Yes

Are the conclusions drawn balanced and justified on the basis of the presented arguments? Yes

Competing Interests: No competing interests were disclosed.

Reviewer Expertise: TB Immunologist

I confirm that I have read this submission and believe that I have an appropriate level of expertise to confirm that it is of an acceptable scientific standard, however I have significant reservations, as outlined above.

Author Response 22 Apr 2018

Frank Cobelens, Department of Global Health and Amsterdam Institute for Global Health and Development, Academic Medical Center, Meibergdreef 9, AZ, The Netherlands

We thank Dr. Divangahi for his valuable comments. 
Here we respond point-by-point, referring to the revised version of our paper.

\section{Major comments}

1: "(...) Although the authors briefly mention this idea, a cohesive expansion of this concept would provide further insight for the important role of type I IFN in viral infection and susceptibility to Mtb".

Response: The reviewer is right to point out that Type I IFN plays a role in HCMV infection as well as in Mtb infection. We expanded the paragraph on viral triggers to include more detail on the possible role of Type I IFN.

2. "The authors need to be cautious about their conclusions regarding a recent paper using nonhuman primate (rhesus macaques) cytomegalovirus vectors encoding Mtb antigens (RhCMV/MTB) (Nature Medicine, 24:130, 2018) for the vaccine in TB. (...)"

Response: We agree with this criticism and now phrased this more cautiously by pointing out that there is currently no widely available HCMV vaccine and it is unclear if vaccines based on HCMV in humans will offer similar protection to those based on RhCMV in nonhuman primates.

3. "The presented human observations that sexual contact and whole blood transfusion are the risk factors for tuberculosis is very speculative. Thus, the author should consider rephrasing this section at least in the abstract as it sounds very confirmative."

Response: We agree that for these two risk factors the evidence base is limited, although we do point out reasons why (e.g. the confounding effect between TB and sexual contact by HIV status). We rephrased this statement in the abstract as "(...) including poor socioeconomic status, solid organ transplantation and, possibly, sexual contact and whole blood transfusion.".

\section{Minor comments}

1. "The age-specific death rates from TB in England and Wales was also reported for 1913 and 1918 that shows the same pattern (Table 2 ) and the authors may want to include this reference:

Langford, C. The age pattern of mortality in the 1918-1919 influenza pandemic: an attempted explanation based on data for England and Wales. Med. Hist. 46, 1-20 (2002)." Response: Indeed TB mortality showed a peak in 1918 in England and Wales, as it did in Switzerland and South Africa (as referenced), as well as in other countries such as The Netherlands (not referenced). This mortality peak has generally been associated with the Spanish Flu epidemic rather than with WW-I, among other because several of these countries were not involved in the war. We feel that this point is rather secondary to our reasoning and does not need additional referencing. Note that mortality peak in 1913 observed by Langford in in England and Wales was observed only in the age group 0-4 years, with little bearing on overall mortality.

In light of this discussion we feel it is important to point out that increased TB mortality during influenza epidemics may reflect increased case fatality among TB patients due to secondary influenza rather than increased TB incidence. We now added this consideration 
to the paragraph on viral triggers of TB.

2. "As there is no evidence of Mtb activating latent HCMV in the lungs (Page 3), which is also not the focus of this review, the author may want to consider removing this entire paragraph."

Response: We agree that this aspect is outside the focus of our review and took out the part of the sentence related to Mtb infection reactivating HCMV infection. We did leave in the remainder of the paragraph but did include a statement that the effect of HCMV on the immunity to Mtb may be systematic as well as local, i.e. in the lungs.

Competing Interests: Apart from being the article's first author I have no competing interests to disclose.

Reviewer Report 14 March 2018

https://doi.org/10.5256/f1000research.15429.r31552

(c) 2018 Strang B. This is an open access peer review report distributed under the terms of the Creative Commons Attribution License, which permits unrestricted use, distribution, and reproduction in any medium, provided the original work is properly cited.

\section{Blair L. Strang}

Institute for Infection and Immunity, St George's, University of London, London, UK

The interaction of different pathogens in an infected individual is a fascinating subject, but, in general, poorly understood. For the most part, it is thought that infection with one pathogen facilities the replication and pathogenesis of another. An example of this is the clear and long standing link between human immunodeficiency virus (HIV) infection and development of severe disease related to MTB mycobacterium tuberculosis (MTB) infection. What is interesting of MTB infection are the concepts of predisposing or preexisting infection other than HIV linked to MTB (for example, the widespread respiratory pathogen influenza.)

In this article, the authors outline intriguing lines of converging evidence detailing the possible association of human cytomegalovirus (HCMV) and MTB infection, suggesting that HCMV infection is a relevant factor in the incidence of MTB disease.

The evidence presented rests largely on epidemiological findings involving age distribution and congruent risk factors. There is an interesting link between the incidence of MTB in early life and adolescence that mirrors acquisition of HCMV either during pregnancy/post partum or by sexual contact in adolescence. Several congruent risk factors are discussed. However, the authors concede that these factors could be applicable to many widespread opportunistic pathogens, including HCMV.

Overall, the argument presented based on epidemiological evidence is compelling and the possible link between HCMV and MTB infection should be investigated further. Indeed, the 
authors should have done more to highlight very resent work from one of their laboratories on this topic. This study, mentioned in the opening paragraphs, shows a clear association of the presence of T cells recognizing HCMV and an increased risk of MTB disease early in life. What is especially interesting about this study is the possibility that development of MTB disease is related to the impairment of NK cell function. Much recent work in HCMV pathogenesis by Wilkinson and colleagues has highlighted the many and diverse mechanisms that HCMV employs to evade NK cells. It is interesting to consider that HCMV evasion of the immune response to infection is directly related to development of MTB disease.

Other points surrounding mechanisms linking HCMV and MTB infection are also unclear. The authors mention that the lung may be a reservoir for HCMV. However, this is based on studies in mice using murine cytomegalovirus (MCMV). The pathology of MCMV does not accurately mirror that of HCMV. Thus, more compelling evidence relating the presence of HCMV in the lung with disease must be presented. Based on the data discussed above, co-incident infection of HCMV and MTB in lung tissue may not be required for disease, but, perhaps, modulation of the immune system.

Finally, the authors consider therapeutic intervention. They highlight the sterling work of Picker and colleagues using rhesus cytomegalovirus (RhCMV) as a vaccine vector. These studies have shown that in non-human primates a RhCMV-MTB vaccine candidate can offer notable protection against challenge with MTB. It must be noted, however, that there is currently no widely available $\mathrm{HCMV}$ vaccine and it is unclear if vaccines based on HCMV in humans will offer similar protection to those based on RhCMV in non-human primates. It may be some time before viable HCMV based vaccines are available. In the short term it may be better to peruse the other suggestion the authors make, which is to trial the use of anti-HCMV drugs in patients with MTB.

Is the topic of the opinion article discussed accurately in the context of the current literature?

Yes

Are all factual statements correct and adequately supported by citations? Yes

Are arguments sufficiently supported by evidence from the published literature? Yes

Are the conclusions drawn balanced and justified on the basis of the presented arguments? Yes

Competing Interests: No competing interests were disclosed.

I confirm that I have read this submission and believe that I have an appropriate level of expertise to confirm that it is of an acceptable scientific standard.

Author Response 22 Apr 2018

Frank Cobelens, Department of Global Health and Amsterdam Institute for Global Health 
and Development, Academic Medical Center, Meibergdreef 9, AZ, The Netherlands

We thank Dr. Strang for his valuable comments.

Here we respond point-by-point, referring to the revised version of our paper.

1. "(... Indeed, the authors should have done more to highlight very resent work from one of their laboratories on this topic. This study, mentioned in the opening paragraphs, shows a clear association of the presence of T cells recognizing HCMV and an increased risk of MTB disease early in life. What is especially interesting about this study is the possibility that development of MTB disease is related to the impairment of NK cell function. Much recent work in HCMV pathogenesis by Wilkinson and colleagues has highlighted the many and diverse mechanisms that HCMV employs to evade NK cells. It is interesting to consider that HCMV evasion of the immune response to infection is directly related to development of MTB disease."

Response: We agree that the possible role of impairment of NK cell function deserves more attention. We now elaborate on this aspect in the section entitled "Human Cytomegalovirus Infection".

2. "The authors mention that the lung may be a reservoir for HCMV. However, this is based on studies in mice using murine cytomegalovirus (MCMV). The pathology of MCMV does not accurately mirror that of HCMV. Thus, more compelling evidence relating the presence of HCMV in the lung with disease must be presented. Based on the data discussed above, coincident infection of HCMV and MTB in lung tissue may not be required for disease, but, perhaps, modulation of the immune system."

Response: We added the following references: Gordon et al, J Exp Med 2017 (a study of donor organs that showed the lung is a major site for CMV DNA) and Poole et al.J Infect Dis 2015 (that found CMV in alvealoar macrophages). But it is also true that CMV may not need to be present in the lung as it impacts the systemic immune response and therefore has an indirect effect still relevant for lung immunity. It is possible that both co-infection of lung AND CMV impact on systemic immune response contribute to TB risk in the CMV infected individual. We added this consideration to the in the section entitled "Human Cytomegalovirus Infection".

3. "It must be noted, however, that there is currently no widely available HCMV vaccine and it is unclear if vaccines based on HCMV in humans will offer similar protection to those based on RhCMV in non-human primates."

Response: We agree with this caveat that we added to the text.

Competing Interests: Apart from being the article's first author I have no competing interests to disclose. 
The benefits of publishing with F1000Research:

- Your article is published within days, with no editorial bias

- You can publish traditional articles, null/negative results, case reports, data notes and more

- The peer review process is transparent and collaborative

- Your article is indexed in PubMed after passing peer review

- Dedicated customer support at every stage

For pre-submission enquiries, contact research@f1000.com 